Article

\title{
National Autonomy or Transnational Solidarity? Using Multiple Geographic Frames to Politicize EU Trade Policy
}

\author{
Gabriel Siles-Brügge ${ }^{1, *}$ and Michael Strange ${ }^{2}$ \\ ${ }^{1}$ Department of Politics and International Studies, University of Warwick, Coventry, CV4 7AL, UK; \\ E-Mail: g.siles-brugge@warwick.ac.uk \\ 2 Department of Global Political Studies, Malmö University, 20506 Malmö, Sweden; E-Mail: michael.strange@mau.se \\ * Corresponding author
}

Submitted: 17 November 2019 | Accepted: 27 February 2020 | Published: 31 March 2020

\begin{abstract}
The article contributes to our understanding of how trade is politicized and how civil society activists manage the tensions between multiple collective action frames in a complex political context. When viewed alongside the Brexit referendum and Trump's US Presidency, it is easy to see the 2013-2016 campaign against a European Union-US Transatlantic Trade and Investment Partnership as a further example of an apparently growing populist 'nationalism.' Yet, in the European context-where campaigning was most visible-there was in fact extensive reliance on, and re-iteration of, a transnational 'European' frame, with antecedents in the 1999-2006 campaign against General Agreement on Trade in Services negotiations. As the article argues, transnational campaigning operates within a nexus of multiple, and sometimes conflicting, geographic frames. In both campaigns discussed here, activists typically engaged with the wider public via the national context and, sometimes, with allusions to 'national autonomy.' However, their activism was dependent upon a frame espousing 'transnational solidarity.' Developed over time, this structured their transnational relations with other groups and more full-time activists.
\end{abstract}

\section{Keywords}

civil society; General Agreement on Trade in Services (GATS); local government; petitions; politicization; trade policy; Transatlantic Trade and Investment Partnership (TTIP)

Issue

This article is part of the issue "Politicization of EU Trade Policy across Time and Space" edited by Dirk De Bièvre (University of Antwerp, Belgium), Oriol Costa (Universitat Autònoma de Barcelona, Spain/IBEI, Spain), Leif Johan Eliasson (East Stroudsburg University, USA) and Patricia Garcia-Duran (University of Barcelona, Spain).

(C) 2020 by the authors; licensee Cogitatio (Lisbon, Portugal). This article is licensed under a Creative Commons Attribution 4.0 International License (CC BY).

\section{Introduction}

Geography is at the centre of trade policy. It defines trade flows. It structures the regulatory environment in which goods and services are sold and investments made. It is most evident in the 'open versus closed' dichotomy through which trade policy is currently viewed. The Trump Presidency in the US is often depicted as marking a sharp return to a more openly protectionist rhetoric along nationalist lines, evoking isolationism. Both sides debating the Brexit impasse have also used explicitly geographic narratives: Advocates of Brexit have framed the
European Union (EU) as a barrier to the UK otherwise accessing global markets, while critics have focused on the need for continued 'frictionless' trade with the UK's closest neighbours. Trade policy more generally operates in a political environment that involves multiple institutional levels, including the sub-national, national and global (see Goff \& Broschek, in press).

This article examines the use of geography as a means to politicize two key moments in the recent history of EU trade policy: the World Trade Organization (WTO) General Agreement on Trade in Services (GATS) negotiations of the early to mid-2000s, and the EU-US 
Transatlantic Trade and Investment Partnership (TTIP) negotiations, in the mid-2010s. The collapse of the TTIP negotiations, coming as it did in the context of the Brexit referendum and the election of Donald Trump as US President, might easily be viewed as yet another example of a 'nationalist backlash' against political and economic globalization. The TTIP campaign was, at some points, supported by political groups on the far-right, and even more left-wing activists utilized references to the restriction of national autonomy to help politicize TTIP as a 'threat' (e.g., Jones, 2014). Yet, to read politicization around TTIP only in reference to these groups and arguments misses the more variegated cleavages underpinning the politicization of trade policymaking. During both the earlier GATS talks and those focused on TTIP, NGOs, which played a central role in politicizing the respective negotiations, utilized a variety of geographic frames that drew on notions of both 'national autonomy' and 'transnational solidarity.' As a result, their activities cannot be labelled simply as either 'anti-' or 'pro-globalization.'

The article begins in Section 2 by clarifying what is meant by 'geographic frames,' and how these drive politicization by civil society actors. Section 2.1 then provides a discussion of the methods and sources used in the subsequent frame analysis. This is undertaken in Sections 3 and 4 , which focus on two campaign devices utilized across both periods. The first is transnational petitions, in which campaign groups formulate a series of joint demands which they or the public sign. The second is 'municipal-level trade contestation,' where civil society actors work closely with local governments in support of their critical demands (Siles-Brügge \& Strange, in press). As we discuss in the concluding Section 5, studying how campaigners utilize a mix of geographic frames has important implications. They are not merely descriptive of the activities and demands of civil society groups or mutually exclusive. Rather, they reflect a desire to engage with the public in a national context while also constructing a transnational network of activists. This leads us to rethink not only the politicization of trade policy, but also how to interpret the political conditions that constrain or favour trade negotiations, going beyond a simple picture of nationalism versus globalism.

\section{The Role of Geographic Frames in Politicization}

Civil society activists have been identified as key drivers of the politicization of EU trade policy over the past two decades (for a review, see Meunier \& Czesana, 2019). They played a central role in bringing the GATS to public attention and are credited with spurring some shifts in the EU's policy position in these negotiations (Strange, 2014 , p. 158). Moreover, during the even more highprofile TTIP talks, the key political cleavage to emerge was not between different economic interest groups, as conventional accounts of trade politics might have suggested, but between transatlantic business alliances sup- portive of the talks and NGOs that were broadly critical (Young, 2016).

We argue that the social movement literature studying such groups uses comparable theoretical building blocks to the politicization literature. This latter literature has argued that three dimensions need to be in play to be able to speak of politicization: an 'expansion of actors and audiences' engaged with an issue; issue 'salience' (significance); and, the 'polarisation of opinion' (de Wilde, Leupold, \& Schmidtke, 2016). The study of social movements, for its part, often adopts a 'contentious politics' approach focused on examining the claims made by civil society actors vis-à-vis governments. This is reminiscent of the notion of polarization, in this case between the 'maker' (social movement/civil society actor) and 'receiver' (often, but not exclusively, a government actor) of the claim (Tilly \& Tarrow, 2015, pp. 7-12).

Our more concrete focus here, however, is on relating the three dimensions of politicization to the strategic use of 'collective action frames' discussed in social movement scholarship. The collective action necessary for a social movement or more loosely organized transnational advocacy network (TAN) to emerge-which must be seen as a precondition of its 'contentious claimsmaking' - is dependent upon a common frame by which individuals may understand their shared activity, attract other individuals, and be represented to their target (e.g., a national government; Benford \& Snow, 2000). Such frames may be used to delineate the terms of polarization, defining in the eyes of activists who the maker and receiver of claims are. Where groups wish to increase the salience of a frame (and associated issue), they might focus on its 'centrality' to the lives of the intended target; its 'experiential commensurability' and its 'cultural resonance,' 'or what Campbell (1988) would call myths' (Benford \& Snow, 2000, pp. 619-622). Finally, where activists wish to drive actor expansion, recent scholarship on framing and ideas has emphasized the role of 'polysemic' or ambiguous frames (or ideas) as 'coalition magnets,' strategically deployed by 'policy entrepreneurs' to bridge potentially disparate interests (Béland \& Cox, 2016). Multiple and ambiguous meanings are said to go hand-in-hand with higher levels of abstraction, where ideas or frames possess greater emotional appeal 'because they tap into a core level of personal and group identity' (Cox \& Béland, 2013, p. 316).

Although drawing on some of its building blocks, our approach does represent a key point of difference in respect of the literature on politicization. This latter body of work has often focused on how transfers of authority from the state to 'higher' levels, such as supranational organizations, might trigger a backlash (e.g., de Wilde et al., 2016). We argue, in contrast, that civil society groups do not just rely on emphasizing national sovereignty, painting supranational institutions as the enemy. Their collective action frames-and contentious politics more broadly-do not always rest on establishing a polarizing fault-line between political activity at the national and 
supranational levels. This is especially relevant where civil society organizations act across national borders, whether through sharing information, strategy, or engaging in coordinated action.

Our argument is thus focused on how geography often becomes salient as a way in which collective action frames used by civil society groups to politicize and contest policy are structured (Cumbers, Routledge, \& Nativel, 2008). Such 'geographic frames' may express difference, by emphasizing the different national origins of activists (e.g., 'Canadian,' 'Kenyan') or 'national autonomy/sovereignty,' in the latter case underscoring the imposition of supranational rules on national governments. But they may also be used to express commonalities between activists that transcend national borders, especially where they might be considered abstract (e.g., 'Global,' 'Latin American,' 'European'). For example, the emotional pull of a perceived community of 'English-speaking peoples' has motivated a, these days influential, TAN in favour of closer economic association between the UK and the Anglosphere and given legitimacy to the associated geographic frame prominently adopted by the UK Government of a 'Global Britain' (Bell \& Vucetic, 2019; Daddow, 2019). This is in spite of the fact that actors within this network marry such frames with an emphasis on preserving UK 'sovereignty' (Rosamond, 2019, p. 415).

With multiple geographic frames sitting side-by-side, activists can be highly strategic with how they use them. In some cases, civil society organizations and TANs may subvert traditional hierarchical orders in order to place the 'local' alongside or above the 'national' or even 'global' (Leitner, Sheppard, \& Sziarto, 2008). By challenging such orders, there is not a clear ranking in which the 'national' has sole jurisdiction of the 'local,' in which the latter can only access the 'global' via the former. Crucially, the binary between the 'national/supranational' is blurred where groups can utilize frames emphasizing national autonomy and transnational solidarity simultaneously to motivate support for their cause. Rather than represent a contradiction, the ambiguity and abstraction of these geographic frames allows them to act as effective 'coalition magnets,' bringing together a broader alliance of groups. In this vein, geographic frames should not be mistaken as a mere description of a 'movement' or its demands but rather as part of a political process of self-representation (Strange, 2014; see also Smith, 2005). They should not simply be taken at face value as they represent deliberate political communication by civil society actors.

Bringing together potentially disparate groups is especially significant when campaigning against trade agreements. These both transcend national boundaries and involve a multitude of different actors, who themselves often communicate with one another via a technical language premised on economic and legal expertise (see Hannah, Scott, \& Trommer, 2016). Civil society activists wishing to politicize such agreements therefore benefit from being able to operate across borders, but also from speaking to a variety of different audiences, notably translating the technical terminology and highlighting its significance to potential supporters.

\subsection{Research Questions, Methodology and Sources}

Building on this framework, our article seeks to address three specific questions:

1) How do geographic frames serve as coalition magnets to link groups, such as those involved in forming a TAN, across borders, leading to actor expansion?

2) How do geographic frames define polarization between the makers and receivers of contentious claims, including across different geographic levels?

3) How do activists use geographic frames to draw out the salience of a trade negotiation so that it is seen as significant in the eyes of relevant actors?

In addressing these questions, the article will also be closely examining the audiences to which different geographic frames are being addressed.

Framing is undertaken wherever activists articulate their common position and demands, and therefore includes both oral and written communication, as well as potentially other devices. However, our frame analysis in this article focuses on two specific instruments-transnational petitions and municipal level trade contestation-as prominent means through which trade politicization manifested itself during both the GATS and TTIP negotiations. In focusing on these instruments, we are not suggesting that the frames expressed here represented a unified civil society position-or that there was not a political debate between groups over the choice of frame to use. But, given limited space, we choose to focus on the frames as articulated through these two instruments for three reasons. Firstly, they involve the explicit and detailed statement of civil society frames in a public setting. They are also prima facie organized on different scales (transnational petitions/meetings versus local government motion), allowing us to explore whether multiple geographic frames are still used in each context. Finally, these instruments were consistently used across both campaign periods (GATS and TTIP), with similar organizations, notably members of the Seattle-to-Brussels (S2B) TAN (Gheyle, 2019 , p. 183), playing a role-allowing for comparison across time. In the remainder of this sub-section we provide an overview of the corpus of textual materials relating to these activities that we focus on in our analysis of civil society frames (see also Tables 1 and 2).

Transnational petitions are utilized by civil society to frame their network and its political demands, typically led by a small core of groups with most signatories (either individuals or other groups) asked only to pro- 
vide their formal support (Strange, 2011). In turn, those nationally-based groups often use the petitions to represent their work when communicating with their supporters via online hyperlinks to the group hosting the petition on their website. Transnational petitions have taken two forms. During the GATS period, the focus was on 'global group petitions' (GGPs), or 'online petitions typically framed as "global," linking sometimes hundreds of advocacy groups behind a common set of critical statements targeting an institution of global governance' and seen as a key instrument of TANs (Strange, 2011, p. 1237). There were five such anti-GATS GGPs, running from December 1999 to June 2005 (for an overview, see Table 1). TTIP campaigning took a different path to the GATS activity, in part due to the creation of the European Citizens' Initiative (ECI). We see this as comparable to a GGP in purpose and transnational reach, but with its geographic scope more explicitly European. It came into being in 2011 as an EU institutional innovation to counter criticism of the EU's supposed 'democratic deficit': one million signatures to an $\mathrm{ECl}$ would oblige the Commission to respond (Szeligowska \& Mincheva, 2012). The STOP TTIP ECl submitted for registration in July 2014 demanded that the Commission and EU Member States cease the TTIP negotiations and that CETA not be ratified (Efler et al., 2014). However, in September 2014, the Commission rejected registration of the $\mathrm{ECl}$ (European Commission, 2014). While this was not unusual, what was significant was that the organizers of the STOP TTIP $\mathrm{ECl}$ chose to create a 'self-organized $\mathrm{ECl}$ ' (sECl), launching it only fifteen days later. Within a year, by early October, organizers 'handed over' what they claimed were 3,263,920 signatures from 23 Member States to the European Commission (Zalan, 2015). The organizers also appealed the Commission's decision to deny the $\mathrm{ECl}$ registration, but the European Court of Justice's finding, overturning the decision, was only announced in May 2017 (Case T-754/14)-after the TTIP negotiations were already on hiatus and CETA ratified by the European Parliament.

Municipal-level trade contestation, meanwhile, has also taken two forms (see Siles-Brügge \& Strange, in press). The first has led activists to pressure municipalities into passing motions that were critical of the GATS and TTIP negotiations. Motions were generally based on templates prepared by NGOs associated with the S2B network, such as the Association for the Taxation of Financial Transactions and for Citizens' Action, known by its French acronym ATTAC (see, e.g., GATSWatch, n.d.; TTIP Free Zones, 2019b). Given space constraints, we focus our analysis on the templates used by ATTAC in Austria and France. These countries together accounted for most motions passed in both periods. During the GATS campaign, previous research has identified 744 motions in France and 388 in Austria (against just under 400 elsewhere); the equivalent figures for the TTIP campaign are 760 in France and 408 in Austria (against 846 elsewhere; Siles-Brügge \& Strange, in press). In the case of
France and the GATS period, we draw on the template used by ATTAC-Rhône, which is similar to that used by other local chapters (e.g., ATTAC 91, 2005).

Municipal activism also involved the organization of a set of (transnational) meetings of NGOs and municipalities that served as evidence of campaign coordination. During the GATS period, the more Francefocused 'States-General of local authorities against GATS' (Bobigny, November 2004) morphed into a European and, later, global 'Convention for the Promotion of Public Services,' held respectively in Liège (October 2015) and Geneva (October 2016; Convention Européenne des Collectivités Locales, 2005, 2006; Crespy, 2016, p. 171). During the TTIP period, there was even stronger evidence of coordination of the various national municipality campaigns, which coalesced around the banner of 'TTIP Free Zones Europe.' Transnational meetings of municipalities, with civil society participation as before (see, e.g., Patterson, 2016), were organized in Barcelona (April 2016), Grenoble (February 2017), and Antwerp (March 2019)-although campaigning was already petering out by the time the second meeting was held (Pan-European meeting of local authorities, 2016; Pan-European meeting of TTIP-free zones, 2017; Not Without Municipalities, 2019). The last meeting in Antwerp did not even issue a statement on their website. Anti-TTIP campaigners ran a single website mapping the extent of municipal engagement and providing an overview of some of the national templates that could be used by local activists (see TTIP Free Zones, 2019a).

In the following sections we turn to analyzing the frames contained within these campaign devices, illustrating how the groups involved have built solidarity across time.

\section{Solidarity in Transnational Petitions}

In the case of the anti-GATS group petitions, there was a combination of frames underscoring both national autonomy-in the national categorization of signatories and the emphasis on protecting governmental regulatory power-and global transnational solidarity (see Table 1 for an overview of the geographic frames and activist groups involved). The use of both ambiguous geographic frames enabled such petitions to serve a double purpose of: a) acting as a coalition magnet, leading to actor expansion through the construction of a transnational network; and b) underscoring the centrality of the issue to groups' supporters in a national context, raising the salience of the GATS. Moreover, while in some cases the geographic frame set up an opposition between the policies adopted by supranational or multinational entities (such as the WTO or multinational corporations) and nation-states, petitions were also addressed from transnational activists to national governments. Polarization on this issue was thus not simply along a national-supranational axis ('we, national citizens/organizations, must resist the imposition of GATS by 
Table 1. Geographic frames in transnational petitions.

\begin{tabular}{|c|c|c|}
\hline & Civil society groups involved & Components of framing strategy and politicization \\
\hline $\begin{array}{l}\text { GATS campaign } \\
\text { - WTO-Shrink or Sink! } \\
\text { (1999) } \\
\text { - Stop the GATS Attack } \\
\text { Now! (2001) } \\
\text { - Nairobi Civil Society } \\
\text { Declaration on the } \\
\text { GATS (2003) } \\
\text { - Evian Challenge (2003) } \\
\text { - Stop the GATS power } \\
\text { play against citizens of } \\
\text { the world! (2005) }\end{array}$ & $\begin{array}{l}\text { WTO-Shrink or Sink! (1999) } \\
\text { - 'Our World Is Not For Sale' network } \\
\text { (429 signatories). } \\
\text { Stop the GATS Attack Now! (2001) } \\
\text { - Polaris Institute, European and } \\
\text { North American groups ( } 563 \\
\text { signatories from } 63 \text { countries). } \\
\text { Nairobi Civil Society Declaration on } \\
\text { the GATS (2003) } \\
\text { - Polaris and European groups, but } \\
\text { predominantly African organizations } \\
\text { ( } 25 \text { signatories). } \\
\text { Evian Challenge (2003) } \\
\text { - } 146 \text { international signatories. } \\
\text { Stop the GATS power play against } \\
\text { citizens of the world! (2005) } \\
\text { - } 148 \text { international signatories. }\end{array}$ & $\begin{array}{l}\text { Centrality (to increase salience) } \\
\text { National autonomy: } \\
\text { - GATS undermines government regulatory power; } \\
\text { - National categorization of signatories. } \\
\text { Polysemy (to drive actor expansion) } \\
\text { Global solidarity in the fight against corporate } \\
\text { power. At times a focus on solidarity with } \\
\text { developing countries and at others on those } \\
\text { affected by EU policies. } \\
\text { Defining the terms of polarization } \\
\text { Opposition not just between national and } \\
\text { supranational actors (e.g., WTO), but also between } \\
\text { transnational actors (activists) and nation-states } \\
\text { over the desirable form of globalization. }\end{array}$ \\
\hline $\begin{array}{l}\text { TTIP campaign } \\
\text { - (Self-organized) } \\
\text { European Citizens' } \\
\text { Initiative } \\
(2014-2015 / 2017)\end{array}$ & $\begin{array}{l}\text { 'Stop TTIP Alliance,' closely linked to } \\
\text { Seattle-to-Brussels. Citizens' } \\
\text { committee included Michael Efler } \\
\text { (Mehr Demokratie), Susan George } \\
\text { (Transnational Institute) and John } \\
\text { Hilary (from War on Want). }\end{array}$ & $\begin{array}{l}\text { Centrality, cultural resonance, and experiential } \\
\text { commensurability (to increase salience) } \\
\text { TTIP as a threat to European standards. } \\
\text { Polysemy (to drive actor expansion) } \\
\text { European solidarity as a means of sustaining } \\
\text { pan-European cooperation. } \\
\text { Defining the terms of polarization } \\
\text { Opposition between different types of European } \\
\text { actor and policy. }\end{array}$ \\
\hline
\end{tabular}

Sources: 11.11.11 et al. (2003), Action Aid Uganda et al. (2003), AFTINET (2001), ARENA (2005), Efler et al. (2014), Gheyle (2019), Third World Network (1999).

supranational institutions'). Rather, it reflected the juxtaposition of an alternative form of globalization advanced by NGOs alongside traditional nation-centric models of political power also mobilized by these activists.

Anti-GATS mobilization emerged in the aftermath of two apparent 'success' stories for campaign groups involved in what has been referred to as the 'global justice movement' (Della Porta, 2007): the collapse of the WTO's Third Ministerial Conference in Seattle in December 1999 and the stalling in 1998 of negotiations towards a proposed Multilateral Agreement on Investment (Egan, 2001). A critical GATS demand entered the first GATSrelevant GGP 'WTO-Shrink or Sink!' that activists groups published in the immediate aftermath of the Seattle protests (Third World Network, 1999). This framed GATS as a threat to government regulatory protection of 'the environment, health, safety and other public interests' (Third World Network, 1999). However, this petition and those that followed reflected a broader balancing act between emphasizing transnational/global solidarity and national sovereignty. Notably, 'WTO-Shrink or Sink' was used at the same time as one of two founding declarations of the 'Our World Is Not For Sale' network. This was formed to facilitate many of the transnational civil society alliances that developed in the build-up and during the Seattle protests. The petition thus also sought to link people across borders in transnational solidarity, noting that 'around the world in rich and poor nations alike, millions of people...fight for a just and sustainable future and against corporate globalization,' whilst listing the signatory groups by country. Governments were presented as largely passive victims or, in the case of the more powerful, as tools for a 'corporate elite' and the 'WTO's allegedly neutral Secretariat' (Third World Network, 1999).

Similarly, the 2001 'Stop the GATS Attack Now!' GGP, promoted by North American and European groups, and coordinated by the Canadian Polaris institute, contained a mixture of geographic frames. It argued that the GATS 2000 negotiations 'create vast new rights and access for multinational service providers and newly constrain government action taken in the public interest worldwide' (AFTINET, 2001). It targeted national governments, 
which were asked to 'immediately invoke a moratorium on the...negotiations' and then follow seven overlapping demands that included asserting governmental responsibility over public services towards basic rights; preventing foreign governments and corporations from undermining public interest laws; and, including citizen organizations within government representation at global trade and investment negotiations (AFTINET, 2001).

That said, some differences in the articulation of the global solidarity frame could also be observed in the GGPs. The 2003 'Nairobi' petition-which came out of a meeting in the Kenyan capital, organized by Polaris and European groups with representatives of African civil society from across the continent-specifically called upon 'developing governments...to promote, protect and reclaim the southern policy space, to review, with a view to withdraw, current commitments and therefore not to make any new commitments in current GATS negotiations' (Action Aid Uganda et al., 2003). Signatory groups were identified by name and country, and the petition was presented as a joint statement of transnational solidarity amongst those signatories (Action Aid Uganda et al., 2003). Similarly, the last petition critical of GATS from 2005 ('Stop the GATS power play against citizens of the world!') was intended to specifically critique the inclusion of services within the then still-ongoing Doha negotiations-since stalled-and problematized GATS as a threat to developing countries. It also reiterated the arguments developed in the earlier petitions that GATS was a device pushed by multinational service corporations to undermine national regulatory space. It targeted the heads of Member-state delegations to the WTO, as well as the WTO Secretariat and key Chairs involved in negotiating GATS 2000. As with most of the GATS-focused petitions, the signatories were identified by name and country, and were framed as 'civil society organizations from around the world' (ARENA et al., 2005). In contrast, while the 2003 'Evian' petition was signed by an international list of groups identified by their name and countries, it was more narrowly focused on the EU's GATS negotiation position and demanded that it exclude water utilities on the basis that it threatened 'vulnerable communities worldwide' (11.11.11 et al., 2003). This may have reflected the fact that European groups utilized the antiGATS campaign to develop a trans-European network intended to link the Seattle protests with the role of the European Commission at the WTO. Suitably titled, the S2B network effectively helped to share critical reports between groups, provided a common voice of critique addressed to EU Member States and the Commission's Directorate-General for Trade, and sometimes helped organize street protests (Strange, 2014).

The TTIP (s)ECl also adopted a more explicitly 'European' geographic frame that focused less on either national autonomy or 'global' solidarity (see Table 1 for an overview). This was underpinned by three dynamics, each broadly corresponding to one of the dimensions of politicization discussed above. Firstly, the
anti-TTIP campaign largely took place in Europe. The EU-US nature of the TTIP talks meant that contestation could have potentially been structured along a transatlantic frame, as reflected in the list of signatory groups to a December 2013 letter (which operated much like a GGP) demanding investor-state dispute settlement (ISDS) be removed from the US-EU discussions (350.org et al., 2013). Of 132 group signatories, the majority were either EU- or US-based ( 86 and 39 respectively). European/EU-based activists, however, ultimately found more traction for their campaign while US civil society groups focused their efforts on campaigning against the Trans-Pacific Partnership. Negotiations on the Trans-Pacific Partnership were already more advanced and TTIP was perceived as less of a threat given EU levels of labour or environmental standards (Siles-Brügge, 2017, p. 472). In the EU, the explicitly European, as opposed to transatlantic, framing of the $\mathrm{sECl}$ helped to not only underscore the centrality of TTIP to targets' lives, but was also culturally and experientially resonant. It helped to draw out the salience of transatlantic negotiations as a specific threat to 'European' regulatory systems/standards-a key element of the civil society campaign against TTIP (Eliasson \& Garcia-Duran, 2019, Ch. 4)-in what has been referred to as '[m]ythmaking in European identity' (Buonanno, 2017, p. 797).

Secondly, the European frame was also linked to the decision to pursue an ECl-even after the Commission's rejection of the initial attempt at registration-despite the additional constraints this imposed. Although the $\mathrm{ECI}$ format featured stringent character limits (see European Commission, 2019), organizers chose to maintain the same short text for use within the signatory forms of the sECl. Organizers also not only established a citizens' committee, but also publicly touted the fact that they had met Member State signature thresholds as prescribed in the relevant EU rules governing ECls (Efler et al., 2014; McKeagney, 2015; Taylor, 2015). As Oleart and Bouza (2018) have noted in a comparison of several ECls, including the one critical of TTIP ('STOP TTIP'), organizers must, when writing the petition text, have in mind both a European audience of potential signatories as well as the European decision-makers to whom the $\mathrm{ECl}$ is formally addressed. The text of the STOP TTIP sECI thus presented TTIP and CETA as a 'threat to democracy and the rule of law' (Efler et al., 2014). It also repeated similar themes seen in the anti-GATS petitions. Specifically, it sought 'to prevent employment, social, environmental, privacy and consumer standards from being lowered and public services (such as water) and cultural assets from being deregulated in non-transparent negotiations' (Efler et al., 2014). However, there was no mention of national autonomy; instead organizers 'support[ed] an alternative trade and investment policy in the EU' (Efler et al., 2014). The framing thus put different types of European actors and policies in opposition to each other within a single public sphere (see also Oleart \& Bouza, 2018), rather 
than polarizing national and supranational actors and levels of political activity.

Thirdly, the transnational 'European' frame seen here was not exclusively a product of the formal requirement that $\mathrm{ECls}$ be written to a trans-EU audience. A product of a wider European 'Stop TTIP Alliance,' its creation and, more importantly, the civil society activity that ensured its life after being rejected by the Commission, was also closely linked to the support of the S2B network (Gheyle, 2019, pp. 195-199; Oleart \& Bouza, 2018, pp. 879-880). Individuals named as its supporters, such as Susan George or John Hilary, were embedded within S2B. Its activists had sought to politicize EU trade negotiations in the period between the GATS and TTIP, but it was only with the launch of the TTIP talks in the summer of 2013 that S2B's efforts played a key role in re-igniting the wider politicization of EU trade policy (Siles-Brügge, 2017, pp. 470, 472-473). In collecting signatures for the self-organized $\mathrm{ECl}$, national groups such as 11.11.11 in Belgium and Global Justice Now (formerly World Development Movement) in the UK played similar roles to their work during the GATS campaign. While there may have been unevenness in the number of signatures collected by the STOP TTIP sECl across Member States, the activity itself was nevertheless characterized by a transnational/European frame and collaboration. The appeal to a polysemic European frame served as a coalition magnet sustaining the expansion of civil society and other actors concerned with TTIP (see Gheyle, 2019, pp. 195-199). This is underscored by the fact that groups deliberately chose the procedural constraints of an EU-level petition even after its registration had been rejected.

\section{Municipal-Level Trade Contestation: From the Global to the Local}

In addition to transnational petitions, both the anti-GATS and anti-TTIP campaigns saw civil society groups turn to 'municipal level trade contestation' as a central device to politicize the negotiations. Activists engaged in a series of concerted efforts to push local, and some regional, governments into passing motions that were critical of these agreements, often based on a template. Their efforts saw local governments across largely Western Europe pass many hundreds of motions over both campaign periods (Siles-Brügge \& Strange, in press). The context for this campaigning was mainly a national one, with campaign groups affiliated with S2B often taking the lead in producing the templates used by local campaigners. As a result, the motions were often addressed to national policymakers who could act where local politicians' competences were seen to be circumscribed. In addition, meetings involving both municipalities and campaigners were organized over both campaign periods, with several issuing summary 'resolutions' or 'declarations.' These reflected efforts at transnational collaborationto expand the number of actors active on the issuewhile also being directed more explicitly at policymak- ers in the TTIP years. There was also a clear overlap between the national/supranational organizations involved in the $\mathrm{sECl} /$ transnational group petitions and the municipal campaigning efforts, which bore the clear imprint of S2B and the wider 'Stop TTIP Alliance' (see TTIP Free Zones, 2019b).

The template resolutions we study here-from the French and Austrian chapters of ATTAC-were focused on rendering the distant concept of international trade negotiations salient for local government representatives and their citizens. They highlighted the possible effects these might have at the local (and national) level, i.e., their 'centrality' to peoples' lives (see Table 2 for an overview of geographic frames and activist groups involved). In the case of the anti-GATS campaign, supranational authority and/or rules were framed as a threat to local and national government autonomy. Polarization was thus also on a national-supranational axis. Thus, a French ATTAC template resolution spoke of how 'GATS applies to all administrative levels, from the State to the communes' and of how international rules limited the 'room for manoeuvre' of local (government) representatives (ATTAC-Rhône, 2005, p. 21, authors' translation). In the case of the Austrian GATS template, the threat to local government service provision was said to come from the intensification of EU competitiveness logics implied by the GATS, although it did also emphasize more positive elements of the EU legal order, notably, the Charter of Fundamental Rights. The resolution also underscored the closeness of local government to citizens, in what might be seen as an attempt to increase the commensurability with individuals' lived experience (STOPP-GATS Kampagne, 2004, pp. 78-79).

The geographic framing during the TTIP period was different. The French national template on TTIP and CETA highlighted how 'ISDS would grant investors exclusive rights to attack states when democratic decisions-taken by public institutions, including local authorities' went against their economic interests (Collectif Stop TAFTA, n.d., p. 1, authors' translation). It also rejected any attempts at 'weakening the national or European regulatory framework' and the 'erosion [of local government] capacity to organize and regulate local sustainable development in the general interest' (Collectif Stop TAFTA, n.d., p. 2, authors' translation). Rather than seeing trade agreements as reinforcing a negative EU political order, as during the GATS period, the Austrian template emphasized how they undermined the EU subsidiarity principle by 'constraining' local decision-maker 'autonomy' (TTIP Stoppen, 2014, pp. 1-2, authors' translation). Trade agreements remained salient to the local level, but the axis of polarization shifted. The core issue was less the imposition of rules from supranational (global and European) to national and local levels of decisionmaking, but rather the constraints placed on democratic decision-making bodies at several levels.

Beyond the more obvious call for a rejection of the relevant trade agreements, the way in which the reso- 
Table 2. Geographic frames in municipal-level trade contestation.

\begin{tabular}{|c|c|c|c|}
\hline & Device & Groups involved & Framing strategy and politicization \\
\hline \multirow[t]{12}{*}{$\begin{array}{l}\text { GATS campaign } \\
(2002-2006)\end{array}$} & \multirow{6}{*}{$\begin{array}{l}\text { Municipal motions. } \\
\text { This article focuses } \\
\text { on the national } \\
\text { templates for: } \\
\text { - Austria } \\
\text { - France }\end{array}$} & ATTAC Austria & $\begin{array}{l}\text { Centrality and experiential } \\
\text { commensurability (to increase salience) }\end{array}$ \\
\hline & & \multirow[t]{5}{*}{ ATTAC France } & $\begin{array}{l}\text { GATS is applicable to and constrains local } \\
\text { decision-making, which is close to } \\
\text { citizens. }\end{array}$ \\
\hline & & & Polysemy (to drive actor expansion) \\
\hline & & & $\begin{array}{l}\text { Motions addressed to national } \\
\text { policymakers and speaking to questions } \\
\text { of process. }\end{array}$ \\
\hline & & & Defining the terms of polarization \\
\hline & & & $\begin{array}{l}\text { GATS represents an imposition on local } \\
\text { and national governments by } \\
\text { international rules and the EU. }\end{array}$ \\
\hline & \multirow{6}{*}{$\begin{array}{l}\text { Transnational } \\
\text { declarations: } \\
\text { - Liège Resolution } \\
\text { (2005) } \\
\text { - Geneva } \\
\text { Declaration (2006) }\end{array}$} & \multirow{5}{*}{$\begin{array}{l}\text { Stated authors of the Liège } \\
\text { Resolution are European local } \\
\text { government representatives, } \\
\text { 'local, national, and } \\
\text { international' trade unionists } \\
\text { and civil society organization } \\
\text { representatives (Convention } \\
\text { Européenne des Collectivités } \\
\text { Locales, 2005, p. 1, authors' } \\
\text { translation). }\end{array}$} & $\begin{array}{l}\text { Centrality and experiential } \\
\text { commensurability (to increase salience) }\end{array}$ \\
\hline & & & Relevance of GATS to the local level. \\
\hline & & & Polysemy (to drive actor expansion) \\
\hline & & & $\begin{array}{l}\text { Link between local and global implications } \\
\text { of GATS, e.g., the Convention name shifts } \\
\text { from 'European' (Liège) to 'Global' } \\
\text { (Geneva). }\end{array}$ \\
\hline & & & Defining the terms of polarization \\
\hline & & $\begin{array}{l}\text { Stated authors of the Geneva } \\
\text { Resolution are European, } \\
\text { Canadian, and South African } \\
\text { local government } \\
\text { representatives, 'local, national } \\
\text { and international' trade } \\
\text { unionists and civil society } \\
\text { organization representatives } \\
\text { (Convention Internationale des } \\
\text { Collectivités Locales, 2006, p. 1, } \\
\text { authors' translation). }\end{array}$ & $\begin{array}{l}\text { The imposition of supranational rules on } \\
\text { 'international, national and local } \\
\text { legislation' (Convention Européenne des } \\
\text { Collectivités Locales, 2005, p. 1, authors' } \\
\text { translation). }\end{array}$ \\
\hline \multirow[t]{5}{*}{$\begin{array}{l}\text { TTIP campaign } \\
(2014-2017)\end{array}$} & \multirow{5}{*}{$\begin{array}{l}\text { Municipal motions. } \\
\text { This article focuses } \\
\text { on the national } \\
\text { templates for: } \\
\text { - Austria } \\
\text { - France }\end{array}$} & ATTAC Austria & $\begin{array}{l}\text { Centrality and experiential } \\
\text { commensurability (to increase salience) }\end{array}$ \\
\hline & & \multirow[t]{4}{*}{ ATTAC France } & $\begin{array}{l}\text { TTIP threatens local, national and } \\
\text { European regulation. } \\
\text { Polysemy (to drive actor expansion) }\end{array}$ \\
\hline & & & $\begin{array}{l}\text { Motions addressed to national } \\
\text { policymakers and speaking to questions } \\
\text { of process. }\end{array}$ \\
\hline & & & Defining the terms of polarization \\
\hline & & & $\begin{array}{l}\text { Supranational negotiations threaten } \\
\text { democratic decision-making at various } \\
\text { levels (local, national, European). }\end{array}$ \\
\hline
\end{tabular}


Table 2. (Cont.) Geographic frames in municipal-level trade contestation.

\begin{tabular}{|c|c|c|}
\hline Device & Groups involved & Framing strategy and politicization \\
\hline $\begin{array}{l}\text { Transnational } \\
\text { declarations: } \\
\text { - Barcelona (2016) }\end{array}$ & $\begin{array}{l}\text { TTIP Free Zones Europe, with } \\
\text { links to Seattle-to-Brussels and } \\
\text { the wider 'Stop TTIP Alliance.' }\end{array}$ & $\begin{array}{l}\text { Centrality, cultural resonance and } \\
\text { experiential commensurability (to } \\
\text { increase salience) }\end{array}$ \\
\hline • Grenoble (2017) & & TTIP undermines European regulatory \\
\hline
\end{tabular}
standards.

\section{Polysemy (to drive actor expansion)}

European focus: signatories of declarations are European municipalities only. Focus on European-level debate.

\section{Defining the terms of polarization}

The local inhabits a European public sphere: TTIP as a threat to European values.

Sources: ATTAC-Rhône (2005), Collectif Stop TAFTA (n.d.), Convention Européenne des Collectivités Locales (2005, 2006), Pan-European Meeting of Local Authorities (2016), Pan-European Meeting of TTIP-free zones (2017), STOPP-GATS Kampagne (2004), TTIP Free Zones (2019a, 2019b), TTIP Stoppen (2014).

lutions framed the negotiating process and their target audience underscored the nationally-based campaigning context for these resolutions, which sought to encourage an expansion in the range of domestic actors taking issue with the GATS. A focus on questions of process was also more ambiguous than statements on content. Both French and Austrian sample resolutions highlighted the lack of transparency in the GATS/TTIP negotiations. The French motions also emphasized the non-involvement of local governments specifically and demanded 'the opening of a national debate' on the GATS/TTIP (ATTAC-Rhône, 2005, p. 21; Collectif Stop TAFTA, n.d., pp. 1-2). Meanwhile, the Austrian motions were predominantly directed at national and regional policymakers; the only exception was a reference to Members of the European Parliament in the TTIP sample motion (STOPP-GATS Kampagne, 2004, p. 78; TTIP Stoppen, 2014, p. 1).

In contrast, the declarations and resolutions issued at international meetings of municipalities sought to more explicitly link local campaigning and trade policy impacts, which had the greatest immediate centrality and experiential commensurability, to transnational problems and activism in an effort to act as a coalition magnet. That said, the nature of transnational solidarity being articulated through polysemic geographic frames varied across both campaign periods, mirroring the shift in discourse between the GATS-related GGPs and the TTIP $\mathrm{sECl}$. The declarations/resolutions to come out of the 'European/International Convention for the Promotion of Public Services' (for the GATS period) and the 'Meeting of Local Authorities/TTIP Free Zones' (for the TTIP period) saw a shift from relying on a greater mix of geographic frames to focusing much more explicitly on the link between the local and the European level (see Table 2 for an overview).
It is not unreasonable to see this as partly reflecting the changed subject matter (global versus transatlantic negotiations), and the desire in the GATS period to appeal beyond (Western) Europe, which saw the vast majority of anti-GATS motions (Siles-Brügge \& Strange, in press). The initial Liège Resolution was authored by 'elected representatives from several European countries'; 'trade unionists' from the 'local, national and international' levels and members of civil society organizations concerned with global issues (Convention Européenne des Collectivités Locales, 2005, p. 1, authors' translation). Authorship of the Geneva Declaration, however, was additionally attributed to local government representatives from Canada and South Africa (Convention Internationale des Collectivités Locales, 2006, p. 1), with the Convention going from being framed as 'European' to 'Global.' However, authorship of the Barcelona and Grenoble Declarations was narrower than the transatlantic scope of the talks. Only European municipalities were listed as signatories-despite the presence and role of social movement organizations in coordinating the pan-European campaign and meeting (see TTIP Free Zones, 2019b)-and the broader TTIP Free Zones campaign itself was explicitly European in scope (TTIP Free Zones, 2019a). The Barcelona Declaration, however, did 'celebrate the social movement which has made [a] European debate possible' (Pan-European Meeting of Local Authorities, 2016, p. 2).

As for the national templates, the move from the GATS to the TTIP period also saw the frame around the restriction of national and local autonomy shift away from emphasizing the imposition of supranational rules. In other words, polarization on the issue was no longer simply defined in terms of an opposition between national and supranational actors and policies, but rather in terms of actors inhabiting the same European public 
sphere/level (see Oleart \& Bouza, 2018). The Liège resolution emphasized the risks of WTO-imposed (public) services liberalization for 'international, national and local legislation,' while also highlighting how EU and national policies endangered public services (Convention Européenne des Collectivités Locales, 2005, p. 1, authors' translation). The Geneva Declaration, meanwhile, similarly stressed the problems associated with the global marketization of public services driven by the WTO, in partnership with the European Commission, with national governments showing 'zeal' in 'accept[ing] and put[ting] into practice' this agenda (Convention Internationale des Collectivités Locales, 2006, p. 1, authors' translation). In contrast, the central diagnostic in the Barcelona Declaration was that at a time of EU crises, 'new generation trade agreements' (TTIP, CETA, TiSA) undermined the 'core' values that the European project should be guided by ('solidarity, respect of freedoms and justice') and instead 'put at risk [local authorities'] capacity to legislate and use public funds' (Pan-European Meeting of Local Authorities, 2016, p. 1). The 'treaties [were] being negotiated in a non-transparent manner, not fulfilling European democratic and participatory standards' (Pan-European Meeting of Local Authorities, 2016, p. 1). The Grenoble Declaration of February 2017 was very similar in its focus on a European problématique. At a time of EU crisis, 'new-general free-trade agreements' undermine 'fundamental values' that should be at the heart of European initiatives to 'reinforc[e] social, economic, environmental and labour rights.' Notably, the Declaration emphasized that '[o]nly rebuilding democracy and reinventing the relationship with citizens can fight the rise of nationalist and xenophobic ideas,' alluding to the '[t]housands of initiatives...already set in motion...in cities and regions' (Pan-European meeting of TTIP-free zones, 2017). Rejecting economic nationalism went hand in hand with accentuating the links between the local/regional and the European.

Coupled with the shift in authorship, the reconfiguration of geographic frames might also be explained by the fact that these latter declarations were not only part of an explicitly European campaign ('TTIP Free zones'), but were also presented as statements from 'governmental' authorities to decision-makers in the EU, national governments and other relevant institutions. Explicitly invoking 'European' values may have served a dual purpose here. For one, it reflected a reliance on a strategy of what has been called 'mimetic challenge,' whereby weaker actors are empowered to challenge authority by adopting techniques and styles such that they nevertheless appear as if conforming (Seabrooke \& Hobson, 2007, p. 16; Siles-Brügge \& Strange, in press). Moreover, and as for the (s)ECl, the focus on the European level, as opposed to transatlantic solidarity, allowed the TTIP/CETArelated declarations to emphasize the specific concerns civil society groups were raising about 'European' regulatory standards, such as the weight attached to the potential dilution of precautionary risk regulation. Such fram- ing not only accentuated the centrality and experiential commensurability of the issue, but was also culturally resonant. Finally, the Grenoble Declaration emerged in a context where opponents of the EU's trade agenda were increasingly tarred with the brush of being economic nationalists after the votes for Brexit and Donald Trump. Differentiating their position became a more pressing concern for European civil society groups campaigning on trade issues (Siles-Brügge, 2017).

\section{Conclusion}

Our central argument in this article has been that the politicization of trade negotiations is not just about a prosovereignty backlash in the face of the supranational exercise of authority. The collective action frames that civil society actors rely on to politicize trade negotiations often emphasize multiple geographies as a means of targeting different authoritative actors, as well as communicating to various supportive audiences.

In both the GATS and TTIP cases, the wider public was commonly addressed via national campaigns, with trade negotiations often framed as a threat to (national) 'government autonomy' as a means of drawing out the salience of the issue. While such frames appeared in the transnational petitions we studied for the GATS period, it was most explicit in the case of municipal level trade contestation, where sample motions focused specifically on the risks of trade agreements for the autonomy of local governments. This made sense as a tactic to politicize local government and citizens-helping to polarize the issue. The focus on the local impacts of trade agreements allowed activists to highlight the centrality and experiential commensurability of trade policy without as much emphasis on national sovereignty. Moreover, in both the petitions and the municipal level activism, the demand for 'national/local autonomy' was made in the context of frames calling for 'transnational solidarity,' which served as polysemic coalition magnets (actor expansion). Both moments of politicization were dominated by European actors, with much of the group-to-group relations within civil society channelled through the trans-European S2B network. As evident in the various GGPs that served to articulate and develop the S2B network, activists consciously chose to combine identification by group and nationality, on one side, with transnational solidaric demands. The resolutions issued by transnational groupings of municipalities in the GATS period also combined such mixed geographic frames.

During the GATS talks, transnational solidaric demands were more global in their reach, in part due to the more encompassing nature of the respective trade negotiations, with a claim that the proposed agreement was a particular threat to developing countries. Despite being a transatlantic negotiation with potential repercussions for other parts of the globe, the TTIP campaign narrowed to focus on the European scene. With US domestic politics focused on the Trans-Pacific Partnership and difficulties 
in presenting EU rules as a threat to US consumer and labour rights, the EU and its Member States provided a richer ground for activists to contest TTIP in culturally and experientially resonant terms, drawing out the salience of the talks as a threat to 'European standards.' The ECI was also in part responsible for the more 'European' frame of the TTIP campaign, with activists choosing to 'selforganize' and collect signatures for their own sECl after being initially rejected registration by the Commission. The ensuing 'European' framing of the petition was therefore quite deliberate and illustrative of efforts to sustain transnational solidarity and expand activism. Choosing to maintain the text and criteria for the formal $\mathrm{ECl}$, activists presented an alternative vision of European integration to that driven by the Commission. The same can be said of the transnational declarations issued by municipalities in the TTIP period, which later also explicitly sought to differentiate their criticism of 'new generation trade agreements' from economic populism. Local government motions prepared by activists in this period also put less emphasis than before on the imposition of supranational rules: Political polarization took place within a European public sphere (see also Oleart \& Bouza, 2018).

Understanding that geographic frames are not just descriptive of 'movements' or NGO demands but, rather, key drivers themselves of politicization, is important to how we study the formation and mobilization of civil society networks. With specific regard to the politicization of trade policy, we need to be careful not to dismiss it as a simple 'nationalist backlash,' but instead examine where activist demands are also supportive of transnational cooperation. Our finding thus challenges the 'transfer of authority' thesis widely found in the politicization literature. It invites us to think about the specific critiques of trade agreements articulated by civil society activists, which may be supportive of certain kinds of supranational policymaking-as the authors of the Barcelona and Grenoble Declarations in particular have been at pains to stress. In practice, critics of trade negotiations may therefore well have much more in common with trade negotiators than either side acknowledge. Claims such activists are 'protectionist' or 'anti-globalist' create false binaries that unnecessarily obfuscate the political issues at hand.

\section{Acknowledgments}

We would like to thank the three anonymous reviewers, the editors, and the other participants of the 'Trade Politicization Workshop' held on 2 July 2018 at the Instituto Barcelona de Estudios Internacionales (IBEI) for their helpful comments as well as Signe Arrhenius and Charlotte Godziewski. We are also grateful to Olga Matsarina, Kate Martincová, and Lars Martínez Ridley for their research assistance on our broader work on municipalities in global trade governance. We would also like to acknowledge the funding support of the IBEI and the Research Fund of the University of Antwerp.

\section{Conflict of Interests}

The authors declare no conflicts of interests.

\section{References}

11.11.11, ACME, Africa-Europe Faith and Justice Network, Agir Ici, AIDWATCH, Alliance for Democracy, . . XminY Solidariteitsfonds. (2003). The Evian challenge: A civil society call for the EU to withdraw its GATS water requests [Petition]. Retrieved from https://www.citizen.org/wp-content/uploads/ evianchallenge.pdf

350.org, Global Marshall Plan Initiative, Greenpeace, IBFAN, International Trade Union Confederation, Naturefriends International, . . . LATINDADD. (2013). Letter to USTR and EU Trade Commissioner [Petition]. Retrieved from https://corporateeurope. org/sites/default/files/attachments/ttip_investment _letter_final.pdf

Action Aid Uganda, Alternative Information and Development Centre, ARENA, Business Watch, Center for International Economic Law, Consumer Information Network, . . . World Development Movement. (2003). Nairobi civil society declaration on the GATS [Petition]. Retrieved from https://lists.peacelink.it/ economia/2003/06/msg00016.html

AFTINET. (2001). ATTENTION: Civil society activists around the world! Stop the GATS attack now! AFTINET. Retrieved from http://www.aftinet.org.au/ campaigns/WTO_GATS/signonstatement1.html

ARENA, ActionAid International, Africa-Europe Faith Justice Network, Afrika-Europa Netwerk, Alab Katipunan, Alliance for Democracy, . . . 11.11.11. (2005). Stop the GATS power play against citizens of the world! [Petition] Retrieved from https://www. oaklandinstitute.org/stop-gats-power-play-againstcitizens-world

ATTAC 91. (2005). Courrier Communes [Letter for Communes]. Essonne: ATTAC Nord-Essonne. Retrieved from https://local.attac.org/attac91/IMG/doc/1_ Courrier_Communes.doc

ATTAC-Rhône. (2005). Motion type à voter par les collectivités locales [Sample motion to be voted on by local governments]. In ATTAC-Rhône (Ed.), L'accord general sur le commerce des services: La marchandisation du monde [The General Agreement on Trade in Services: The marketization of the world] (p. 21). Lyon: ATTAC-Rhône.

Béland, D., \& Cox, R. H. (2016). Ideas as coalition magnets: Coalition building, policy entrepreneurs, and power relations. Journal of European Public Policy, 23(3), 428-445.

Bell, D., \& Vucetic, S. (2019). Brexit, CANZUK and the legacy of empire. British Journal of Politics and International Relations, 21(2), 367-382. https://doi.org/ $10.1177 / 1369148118819070$

Benford, R., \& Snow, D. (2000). Framing processes and 
social movements. Annual Review of Sociology, 26(1), 611-639.

Buonanno, L. A. (2017). The new trade deals and the mobilisation of civil society organizations: Comparing EU and US responses. Journal of European Integration, 39(7), 795-809.

Collectif Stop TAFTA. (n.d.). Resolution 2 finale [Final resolution 2]. Paris: ATTAC France. Retrieved from https://www.collectifstoptafta.org/IMG/pdf/ resolution2-finale.pdf

Convention Européenne des Collectivités Locales. (2005). Résolution de Liège [Liège Resolution]. Liège: Convention Européenne des Collectivités Locales. Retrieved from https://www.quebec.attac.org/IMG/ pdf/resolutionLiege2005.pdf

Convention Internationale des Collectivités Locales. (2006). Déclaration commune [Common declaration]. Geneva: Convention Internationale des Collectivités Locales. Retrieved from https://www.quebec. attac.org/IMG/pdf/declarationfinale2006.pdf

Cox, R. H., \& Béland, D. (2013). Valence, policy ideas, and the rise of sustainability. Governance, 26(2), 307-328.

Crespy, A. (2016). Welfare markets in Europe. London: Palgrave Macmillan.

Cumbers, A., Routledge, P., \& Nativel, C. (2008). The entangled geographies of global justice networks. Progress in Human Geography, 32(2), 183-201.

Daddow, O. (2019). Global Britain ${ }^{\mathrm{TM}}$ : The discursive construction of Britain's post-Brexit role. Global Affairs, 5(1), 5-22.

Della Porta, D. (Ed.). (2007). The global justice movement: Cross-national and transnational perspectives. Boulder, CO: Paradigm.

de Wilde, P., Leupold, A., \& Schmidtke, H. (2016). Introduction: The differentiated politicisation of European governance. West European Politics, 39(1), 3-22.

Efler, M., de Birto e Abreu Krupenski, P., Andrei, I.-L., Hilary, J., George, S., Weber, B. L. D., \& Kronqvist, O. J. (2014). Stop TTIP. European Union. Retrieved from https://ec.europa.eu/citizens-initiative/public/ initiatives/obsolete/details/2017/000008

Egan, D. (2001). The limits of internationalization: A neoGramscian analysis of the multilateral agreement on investment. Critical Sociology, 27(3), 74-97.

Eliasson, L. J., \& Garcia-Duran, P. (2019). Civil society, rhetoric of resistance, and transatlantic trade. London: Palgrave Macmillan.

European Commission. (2014). Your request for registration of a proposed citizens' initiative entitled 'STOP TTIP'. Letter to Mr Michael Efler (10 September, C(2014) 6501 final). Brussels: European Commission.

European Commission. (2019). How it works. European Citizens' Initiative. Retrieved from https://europa. eu/citizens-initiative/how-it-works_en

GATSWatch. (n.d.). Stop the GATS attack: Involving local and regional governments. Retrieved from http:// www.gatswatch.org/locgov-list.html
Gheyle, N. (2019). Trade policy with the lights on: The origins, dynamics, and consequences of the politicization of TTIP (Unpublished Doctoral thesis). Ghent University, Ghent, Belgium.

Goff, P., \& Broschek, J. (Eds.). (in press). Multilevel trade politics: Configurations, dynamics, mechanisms. Toronto: University of Toronto Press.

Hannah, E., Scott, J., \& Trommer, S. (Eds.). (2016). Expert knowledge in global trade. Abingdon: Routledge.

Jones, O. (2014, September 14). The TTIP deal hands British sovereignty to multinationals. The Guardian. Retrieved from https://www.theguardian.com/ commentisfree/2014/sep/14/ttip-deal-britishsovereignty-cameron-ukip-treaty

Leitner, H., Sheppard, E., \& Sziarto, K. (2008). The spatialities of contentious politics. Transactions of the Institute of British Geographers, 33(2), 157-172.

McKeagney, S. (2015, October 7). Self-organised ECI reaches 3 million signatures! TTIP-Beware What Lies Beneath. Retrieved from https://ttip2016.eu/ blog/ECl\%203\%20Million\%20TTIP\%20CETA.html

Meunier, S., \& Czesana, R. (2019). From back rooms to the street? A research agenda for explaining variation in the public salience of trade policy-making in Europe. Journal of European Public Policy, 26(2), 1847-1865.

Not Without Municipalities. (2019). Homepage. Not Without Municipalities. Retrieved from http:// notwithoutmunicipalities.com

Oleart, A., \& Bouza, L. (2018). Democracy at stake: Multipositional actors and politicization in the EU civil society field. Journal of Common Market Studies, 56(4), 870-887.

Pan-European Meeting of Local Authorities. (2016). Barcelona declaration. Barcelona: Pan-European Meeting of Local Authorities. Retrieved from http:// www.noalttip.org/wp-content/uploads/2015/10/ Declaracio\%CC\%81-final-amb-esmenes-ANG..pdf

Pan-European Meeting of TTIP-free zones. (2017). Declaration of the second pan-European meeting of TTIP-free zones. Grenoble: Pan-European Meeting of TTIP-free zones. Retrieved from https:// www.collectifstoptafta.org/actu/article/grenoble-sresponse

Patterson, B. (2016). Council of Canadians at municipal conference in Barcelona opposed to CETA, TTIP \& TISA. Council of Canadians. Retrieved from https:// canadians.org/blog/council-canadians-municipalconference-barcelona-opposed-ceta-ttip-tisa

Rosamond, B. (2019). Brexit and the politics of UK growth models. New Political Economy, 24(3), 408-421.

Seabrooke, L., \& Hobson, J. M. (2007). Everyday politics of the world economy. Cambridge: Cambridge University Press.

Siles-Brügge, G. (2017). Transatlantic investor protection as a threat to democracy: The potency and limits of an emotive frame. Cambridge Review of International Affairs, 30(5), 464-488.

Siles-Brügge, G., \& Strange, M. (in press). Municipal level 
trade contestation: Activists and local governments from the MAI to TTIP. In J. Broschek \& P. Goff (Eds.), Multilevel trade politics: Configurations, dynamics, mechanisms. Toronto: University of Toronto Press.

Smith, J. (2005). The uneven geography of global civil society: National and global influences on transnational association. Social Forces, 84(2), 622-652.

STOPP-GATS Kampagne. (2004). Resolution des Gemeinderats: Stopp dem Ausverkauf der öffentlichen Dienstleistungen und der Privatisierung der Grundversorgung der Bevölkerung [Resolution of the local council: stop the selling off of public services and the privatization of peoples' basic services]. In STOPPGATS Kampagne (Ed.), Die Stopp GATS Kampagne: Analysen, Hintergründe, Perspektiven [The Stop GATS campaign: Analyses, background, perspectives] (pp. 78-84). Vienna: STOPP-GATS Kampagne.

Strange, M. (2011). 'Act now and sign our joint statement!' What role do online global group petitions play in transnational movement networks? Media, Culture \& Society, 33(8), 1236-1253.

Strange, M. (2014). Writing global trade governance: Discourse and the WTO. Abingdon: Routledge.

Szeligowska, D., \& Mincheva, E. (2012). The European citizens' initiative-Empowering European citizens within the institutional triangle: A political and legal analysis. Perspectives on European Politics and Soci- ety, 13(3), 270-284.

Taylor, G. (2015). Joint 1.5 million. No TTIP times (No.3). Retrieved from https://www.globaljustice.org.uk/ sites/default/files/files/resources/nottip_times_3_ web.pdf

Third World Network. (1999). WTO-Shrink or sink! The turn around agenda. Third World Network. Retrieved from https://www.twn.my/title/shrink.htm

Tilly, C., \& Tarrow, S. (2015). Contentious politics (2nd ed.). Oxford: Oxford University Press.

TTIP Free Zones. (2019a). TTIP free zones Europe. TTIP Free Zones. Retrieved from https://www.ttip-freezones.eu

TTIP Free Zones. (2019b). Take Action. Retrieved from https://www.ttip-free-zones.eu/vews-country

TTIP Stoppen. (2014). Resolution: TTIP/CETA/TiSA-freie Gemeinde [Resolution: TTIP/CETA/TiSA-free municipality]. Vienna: ATTAC Austria. Retrieved from https://www.ttip-stoppen.at/wp-content/uploads/ 2014/11/resolution_neu_gdg.pdf

Young, A. R. (2016). Not your parents' trade politics: The Transatlantic Trade and Investment Partnership negotiations. Review of International Political Economy, 23(3), 345-378.

Zalan, E. (2015, October 7). Stop TTIP' activists hand EU $3 \mathrm{mn}$ signatures. EU Observer. Retrieved from https:// euobserver.com/institutional/130587

\section{About the Authors}
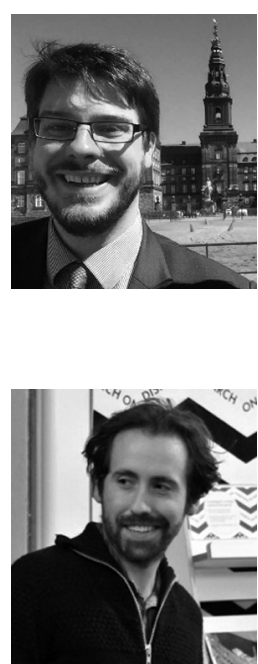

Gabriel Siles-Brügge is Associate Professor in Public Policy at the University of Warwick. His current research focuses on the municipal-level contestation of trade and investment agreements, the role of emotion in trade and investment policy and the political economy of Brexit. He has served as an unpaid Scientific Advisor on trade and investment policy to the European Public Health Alliance (EPHA) since 2015, and has more recently begun representing the organization as an alternate member of the European Commission's 'Expert group on Trade Agreements.' During part of the TTIP campaign he also acted in an unpaid capacity as President of the Health and Trade Network, an organization that, like EPHA, also campaigned on TTIP.

Michael Strange is Reader in International Relations at Malmö University. Along with his current research on municipal level trade contestation, he is more broadly interested in the emergence of new actors in shaping governance at all levels. His work includes trade politics, as well as migration, health, and extra-institutional forms of democracy. His oral evidence on municipalities in trade politics to the UK House of Commons International Trade Committee was cited in its closing report to the UK Government on UK Trade Policy Transparency and Scrutiny after Brexit. 